\title{
Efforts to Improve Learning Outcomes Using Video Media for Grade 6 Students of Wadasmalang 3 Public Elementary Schools, Karangsambung District Kebumen Academic Year 2020/2021
}

\section{Triyono}

SD Negeri 3 Wadasmalang

trianangyono@gmail.com

Article History

accepted 14/11/2020

approved 21/11/2020

published 26/11/2020

\begin{abstract}
The purpose of this study was to improve student learning outcomes in learning theme 5 in grade $\mathrm{VI}$ elementary schools using video learning media. The research conducted was a Classroom Action Research (CAR) consisting of three cycles. The stages of each cycle were planning, implementing, observing and reflecting. Each meeting is carried out an assessment of knowledge, skills and attitudes to determine the development of students. In cycle I, students who completed after carrying out the knowledge assessment were $70 \%$. In cycle II students who completed after carrying out the knowledge assessment were $87 \%$. In cycle III students who completed after carrying out the knowledge assessment were 93\%. These results indicate that the use of video media can improve student learning outcomes, especially the theme of Class VI at SDN 3 Wadasmalang..
\end{abstract}

Keywords: Learning Outcomes, Videos, Themes 5

\section{Abstrak}

Tujuan dari penelitian ini adalah untuk meningkatkan hasil belajar peserta didik pada pembelajaran tema 5 di sekolah dasar kelas VI dengan media pembelajaran video. Penelitian yang dilakukan adalah Penelitian Tindakan Kelas (PTK) sebanyak tiga siklus, Tahapan setiap siklusnya adalah perencanaan, pelaksanaan, observasi dan refleksi. Setiap pertemuan dilakukan penilaian pengetahuan, keterampilan dan sikap untuk mengetahui perkembangan peserta didik. Pada siklus I peserta didik yang tuntas setelah melaksanakan penilaian pengetahuan sebesar $70 \%$. Pada siklus II peserta didik yang tuntas setelah melaksanakan penilaian pengetahuan sebesar $87 \%$. Pada siklus III peserta didik yang tuntas setelah melaksanakan penilaian pengetahuan sebesar $93 \%$. Hasil ini menunjukan bahwa penggunaan media video dapat meningkatkan hasil belajar peserta didik khususnya tema 5 Kelas VI di SDN 3 Wadasmalang.

Kata kunci: Hasil belajar, Video, Tema 5

Social, Humanities, and Education Studies (SHEs): Conference Series https://jurnal.uns.ac.id/shes 


\section{PENDAHULUAN}

Peningkatan relevansi pendidikan dimaksudkan untuk menghasilkan lulusan yang sesuai dengan tuntutan kebutuhan berbasis potensi sumber daya alam Indonesia. Peningkatan efisiensi manajemen pendidikan dilakukan melalui penerapan manajemen berbasis sekolah dan pembaharuan pengelolaan pendidikan secara terencana, terarah, dan berkesinambungan. Hal ini sesuai dengan Permendiknas No. 22 Tahun 2006

Peningkatan mutu pendidikan di Sekolah Dasar merupakan prioritas utama di kalangan pendidikan dalam rangka peningkatan sumber daya manusia sebab sekolah dasar merupakan jenjang pendidikan formal yang pertama yang mempunyai tanggung jawab untuk mengembangkan sikap dan kemampuan serta memberikan pengetahuan dan ketrampilan dasar sebagai bekal hidup di masyarakat.

Ada beberapa pengertian tentang hasil belajar. Dibawah ini dikemukakan pengertian hasil belajar menurut beberapa ahli.

Skinner dalam Sagala (2010:14) mendefiniskikan belajar adalah suatu proses adaptasi atau penyesuaian tingkah laku yang berlangsung secara progresif dan berkelanjutan. Menurut Gagne dalam Sagala (2010:17) belajar adalah perubahan yang terjadi dalam kemampuan manusia yang terjadi setelah belajar secara terus $\neg$ menerus, bukan hanya disebabkan oleh proses pertumbuhan saja.

Menurut Dimyati dan M udjiono (1999:250) hasil belajar dapat dipandang dari dua sisi yaitu sisi siswa dan dari sisi guru. Dari sisi siswa, hasil belajar merupakan tingkat perkembangan mental pada ranah kognitif, afektif, dan psikomotorik yang lebih baik bila dibandingkan pada saat sebelum belajar. Sedangkan dari sisi guru, hasil belajar merupakan saat terselesaikannya bahan pelajaran

Dalam penggunaan media pembelajaran yang akan digunakan dalam penelitian ini adalah media video. Media video merupakan salah satu jenis media pembelajaran yang bersifat media audio visual. Menurut Kamus Besar Bahasa Indonesia dalam Prastowo (2012:300) mengartikan video merupakan rekaman gambar hidup atau program televisi melalui tayangan dengan gambar yang bergerak disertai dengan suara.

Uno dan Lamatenggo (2010:137) mengemukakan "Media video membantu pengajar untuk menjelaskan gerakan atau prosedur tertentu dengan lebih rinci". Sehingga dapat disimpulkan media video adalah media pembelajaran yang membantu pengajar dalam menyampaikan materi dengan lebih mudah dan rinci menggunakan efek gambar bergerak dan suara.

\section{METODE}

Penelitian ini adalah penelitian tindakan kelas (Classroom Action Research) dengan penggunaan media video. Menurut Kurt Lewin dalam Kunandar (2011: 42) penelitian tindakan kelas ini terdiri dari empat tahapan dasar yaitu perencanaan (planning), pelaksanaan (acting), pengamatan (observing) dan refleksi (reflecting). Analisis penelitian ini adalah analisis deskriptif kuantitafif kualitatif dimana dalam penelitian ini selain penyajian hasil berupa data maupun angka peneliti juga menentukan bagaimana cara pengolahan hasil penelitian yakni dengan membuat analisisnya dengan menerapkan media video. Penelitian ini dilaksanakan pada peserta didik kelas VI SD Negeri 3 Wadasmalang Tahun Pelajaran 2020/2021 selama tiga siklus secara daring menggunakan aplikasi Google meet. Siklus I dilaksanakan pada tanggal 2 November 2020. Siklus II dilaksanakan pada tanggal 9 November 2020. Siklus II dilaksanakan pada tanggal 20 November 2020. Teknik pengumpulan data yang dilakukan dengan observasi dan penilaian, baik penilaian pengetahuan, sikap dan keterampilan. Observasi meliputi observasi keterlaksanaan penggunaan media video dalam pembelajaran, sikap peserta didik dan keterampilan. Untuk hasil belajar menggunakan tes melalui Google form. 


\section{HASIL DAN PEMBAHASAN}

Pada siklus I pembelajaran dilaksanakan selama 1 kali pertemuan, Untuk mengetahui perkembangan peserta didik selama pembelajaran. Siklus I membahas Tema 5 (Wirausaha) Subtema 1 (Kerja keras berbuah kesuksesan) Pembelajaran ke-1 dengan muatan pelajaran Bahasa Indonesia, IPA, IPS. Pembelajaran dengan penggunaan media video dilaksanakan melalui 4 langkah yaitu perencanaan, pelaksanaan, evaluasi dan refleksi. Proyek yang dibuat peserta didik adalah menyusun laporan sederhana tentang sifat-sifat magnet berdasarkan hasil percobaan. Berikut ini adalah hasil belajar peserta didik pada siklus I yang bisa dilihat pada tabel berikut.

Tabel 1. Hasil Penilaian Siklus I

\begin{tabular}{l|c|c|c|c}
\hline \multirow{2}{*}{$\begin{array}{c}\text { Ketuntasan } \\
\text { SIKLUS I }\end{array}$} & \multirow{2}{*}{ PENGETAHUAN } & \multicolumn{3}{|c}{ KETERAMPILAN } \\
\cline { 3 - 5 } & & B. INDO & IPA & IPS \\
\hline Tuntas & 21 & 21 & 21 & 24 \\
\hline Prosentase & $70 \%$ & $70 \%$ & $70 \%$ & $80 \%$ \\
\hline Belum Tuntas & 9 & 9 & 9 & 6 \\
\hline Prosentase & $30 \%$ & $30 \%$ & $30 \%$ & $20 \%$ \\
\hline
\end{tabular}

Dari data di atas diperoleh data sebagai berikut: Pada pelaksanaan pembelajaran daring siklus 1 sebanyak 21 siswa atau 70\% sudah mencapai Kriteria Ketuntasan Minimal. Sebanyak 9 siswa atau 30\% belum mencapai Kriteria Ketuntasan minimal. Aspek keterampilan mupel Bahasa Indonesia dengan materi tentang Formulir sebanyak 21 siswa atau 70\% sudah mencapai Kriteria Ketuntasan Minimal sedangkan 9 siswa atau 30\% belum mencapai Kriteria Ketuntasan minimal Aspek keterampilan mupel IPA dengan materi tentang magnet sebesar sebanyak 21 siswa atau $70 \%$ sudah mencapai Kriteria Ketuntasan Minimal). Sebanyak 9 siswa atau 30\% belum mencapai Kriteria Ketuntasan minimal. Aspek keterampilan mupel IPS tentang Possi dan peran Indonesia bidang ekonomi di lingkup ASEAN Sebanyak 24 siswa atau $80 \%$ sudah mencapai Kriteria Ketuntasan Minimal sedangkan 6 siswa atau 20\% belum mencapai.

Pada siklus II pembelajaran dilaksanakan selama 1 kali pertemuan, Untuk mengetahui perkembangan peserta didik selama pembelajaran. Siklus II membahas Tema 5 (Wirausaha) Subtema 2 (Membangun Masyarakat Sejahtera) Pembelajaran ke-5 dengan muatan pelajaran IPS dan SBdP. Pembelajaran dengan penggunaan media video dilaksanakan melalui 4 langkah yaitu perencanaan, pelaksanaan, evaluasi dan refleksi. Proyek yang dibuat peserta didik adalah menyusun laporan sederhana tentang sifat-sifat magnet berdasarkan hasil percobaan. Berikut ini adalah hasil belajar peserta didik pada siklus II yang bisa dilihat pada tabel berikut.

Tabel 2. Hasil Penilaian Siklus II

\begin{tabular}{l|c|c|c}
\hline \multirow{2}{*}{$\begin{array}{c}\text { Ketuntasan } \\
\text { SIKLUS II }\end{array}$} & \multirow{2}{*}{ PENGETAHUAN } & \multicolumn{2}{|c}{ KETERAMPILAN } \\
\cline { 2 - 4 } & & IPS & SBdP \\
\hline Tuntas & 26 & 27 & 28 \\
\hline Prosentase & $87 \%$ & $90 \%$ & $93 \%$ \\
\hline Belum Tuntas & 4 & 3 & 2 \\
\hline Prosentase & $13 \%$ & $10 \%$ & $7 \%$ \\
\hline
\end{tabular}

Dari data di atas diperoleh data sebagai berikut: Pada pelaksanaan pembelajaran daring siklus II sebanyak 26 siswa atau $87 \%$ sudah mencapai Kriteria Ketuntasan Minimal sedangkan 4 siswa atau 13\% belum mencapai Kriteria Ketuntasan 
minimal. Aspek keterampilan IImu Pengetahuan Sosial dengan materi tentang Komoditas Ekspor dan Impor Indonesia ke Negara-negara ASEAN sebanyak 27 siswa atau $90 \%$ sudah mencapai Kriteria Ketuntasan Minimal sedangkan 3 siswa atau 10\% belum mencapai Kriteria Ketuntasan minimal Aspek keterampilan mupel SBdP dengan materi tentang membuat poster sebesar sebanyak 28 siswa atau 93\% sudah mencapai Kriteria Ketuntasan Minimal. Sedangkan 2 siswa atau 7\% belum mencapai Kriteria Ketuntasan minimal.

Pada siklus III pembelajaran dilaksanakan selama 1 kali pertemuan, Untuk mengetahui perkembangan peserta didik selama pembelajaran. Siklus III membahas Tema 5 (Wirausaha) Subtema 3 (Ayo belajar Berwirausaha) Pembelajaran ke-2 dengan muatan pelajaran PPKn dan SBdP. Pembelajaran dengan penggunaan media video dilaksanakan melalui 4 langkah yaitu perencanaan, pelaksanaan, evaluasi dan refleksi. Proyek yang dibuat peserta didik adalah menyusun laporan sederhana tentang sifat-sifat magnet berdasarkan hasil percobaan. Berikut ini adalah hasil belajar peserta didik pada siklus II yang bisa dilihat pada tabel berikut.

Tabel 3. Hasil Penilaian Siklus III

\begin{tabular}{l|c|c|c}
\hline \multirow{2}{*}{$\begin{array}{c}\text { Ketuntasan } \\
\text { SIKLUS II }\end{array}$} & \multirow{2}{*}{ PENGETAHUAN } & \multicolumn{2}{|c}{ KETERAMPILAN } \\
\cline { 3 - 4 } & & PPKn & SBdP \\
\hline Tuntas & 28 & 28 & 30 \\
\hline Prosentase & $93 \%$ & $93 \%$ & $100 \%$ \\
\hline Belum Tuntas & 2 & 2 & 0 \\
\hline Prosentase & $7 \%$ & $7 \%$ & $0 \%$ \\
\hline
\end{tabular}

Dari data di atas diperoleh data sebagai berikut: Pada pelaksanaan pembelajaran daring siklus III sebanyak 28 siswa atau 93\% sudah mencapai Kriteria Ketuntasan Minimal sedangkan 2 siswa atau 7\% belum mencapai Kriteria Ketuntasan minimal. Aspek keterampilan mupel PPKn dengan materi tentang manfaat keberagaman wirausaha sebanyak 28 siswa atau 93\% sudah mencapai Kriteria Ketuntasan Minimal sedangkan 2 siswa atau 7\% belum mencapai Kriteria Ketuntasan minimal Aspek keterampilan mupel SBdP dengan materi tentang membuat embalase sebanyak 30 siswa atau 100\% sudah mencapai Kriteria Ketuntasan Minimal..

\section{SIMPULAN}

Berdasarkan temuan dan analisis yang diperoleh dalam pelaksanaan pembelajaran daring Tema 5 (Wirausaha) dengan menggunakan media video dari siklus I, sampai siklus III, dapat disimpulkan bahwa: Penggunaan media video dapat meningkatkan hasil belajar siswa kelas 6 SD Negeri 3 Wadasmalang Tahun 2020/2021

Dengan demikian peneliti berpendapat bahwa perbaikan pembelajaran menggunakan media video khususnya dalam pembelajaran daring Tema 5 (Wirausaha) adalah salah satu langkah untuk meningkatkan pemahaman siswa terhadap suatu konsep/materi serta untuk meningkatkan hasil belajar siswa.

\section{DAFTAR PUSTAKA}

Anitah, S. (2009). Teknologi Pembelajaran. Surakarta: Yuma Pustaka.

Arikunto, S., Suhardjono, Supardi. (2010). Penelitian Tindakan Kelas. Jakarta: Bumi Aksara.

Arsyad, A. (2011). Media Pembelajaran. Jakarta: Raja Grafindo Persada.

Departemen Pendidikan dan Kebudayaan. (2014). Kamus Besar Bahasa Indonesia. Jakarta: Departemen Pendidikan dan Kebudayaan.

Djamarah, S. B. \& Zain, A. (2013). Strategi Belajar Mengajar. Jakarta: Rineka Cipta. 
Eun-Young, P., \& Young-Ho, P. (2010). A Hierarchical Interface Design of a Puzzle Game for Elementary Education. Science and Technology, 3 (2), 43-50.

Haryanto. (2011). Pengertian Model Pembelajaran. Diperoleh pada tanggal 16 November 2014 dari http://belajarpsikologi.com/pengertian-model-pembelajaran/.

Hamdani. (2011). Strategi Belajar Mengajar. Bandung: Pustaka Setia..

Rusman. 2012. Model-model Pembelajaran. Bandung: Rajagrafindo Persada.

Shoimin, A. (2014). 68 Model Pembelajaran Inovatif dalam Kurikulum 2013. Yogyakarta: Ar-Ruzz Media.

Sugiyono. (2012). Metode Penelitian Pendidikan (Pendekatan Kuantitatif, Kualitatif, dan $R \& D)$. Bandung: Alfabeta.

Wardhani, I., dkk. (2009). Penelitian Tindakan Kelas. Jakarta: Universitas Terbuka.

Wena, M. (2011). Strategi Pembelajaran Inovatif Kontemporer. Edisi 1 Cetakan ke 6. Jakarta: Bumi Aksara.. 